\title{
Kontribusi Keputusan Operasi dalam Pencapaian Keunggulan Bersaing Biaya Rendah (Low Cost) pada Monica Collection Semarang
}

\author{
Veronica Kusdiartini; Agustine Eva Maria Soekesi; \\ Meniek Srining Prapti; Bayu Perstianto \\ kusdiartiniveronica@yahoo.co.id
}

Fakultas Ekonomi dan Bisnis Universitas Katolik Soegijapranata

\begin{abstract}
This research result gives contribution to Decision on Operation in achieving Low Cost Competitive Advantage in Monica Collection Semarang. Realizing this objective, it should be conducted research in operation decision supporting Monica Collection company to achieve its competitive advantage based on low cost. In this research it was found that there was operation decision conducted which supporting this low cost competitive advantage.
\end{abstract}

Keywords : operation decision; competitive advantage; low cost.

\section{PENDAHULUAN}

UMKM dapat bertahan bahkan berkembang karena melakukan kegiatan dari sisi inovasi produk, pengembangan sumber daya manusia, pengembangan teknologi, pengembangan dan perluasan pasar. Salah satu jenis industri yang masuk dalam kelompok UMKM adalah industri konfeksi. Konfeksi adalah salah satu industri kecil skala rumah tangga yang merupakan tempat pembuatan pakaian jadi seperti kaos, kemeja, celana, jaket dan sebagainya. Pada kenyataan saat ini terjadi kekeliruan penyebutan istilah, dimana istilah konfeksi banyak disebut dengan istilah konveksi.

Monica Collection adalah sebuah perusahaan yang bergerak di bidang konfeksi di J1. Puri Anjasmoro B2/5 Semarang. Produk yang diproduksi adalah Bedding (sprei, bed cover, sarung bantal guling), perlengkapan bayi (topi, kasur, selimut), Gorden. Usaha konfeksi ini dikembangkan oleh Ibu Hana Lila Yuliana W, sebagai pemilik sekaligus pemimpin perusahaan. Jumlah pegawai Monica Collection Semarang adalah 15 orang karyawan, yang mayoritas adalah tenaga kerja operasional (penjahit). Kegiatan produksi dimulai dari jam 08.00 sampai dengan jam 17.00 (1 shift kerja).

Kegiatan pra survey penelitian ini mengidentifikasi bahwa keunggulan bersaing dari perusahaan ini adalah Low Cost atau keunggulan produksi dengan biaya rendah. Hal 
ini dipilih karena perusahaan menetapkan strategi harga yang kompetitif. Dalam arti berani menjual lebih rendah dari pada pesaing. Dari permasalahan yang diuraikan di atas, maka dalam penelitian ini tema penelitiannya adalah "Kontribusi Keputusan Operasi dalam Pencapaian Keunggulan Bersaing Biaya Rendah (Low Cost) pada Monica Collection Semarang". Berdasarkan latar belakang masalah maka perumusan masalah dalam penelitian ini adalah: bagaimana kontribusi keputusan operasi dalam pencapaian keunggulan bersaing biaya rendah (Low Cost) pada Monica Collection Semarang?

\section{TINJAUAN PUSTAKA}

\section{Strategi Operasi}

Sebagai sebuah bisnis kendala dalam hal persaingan menjadi kendala utama. Banyaknya pesaing dari dalam Kota Semarang maupun dari kota lain karena pada bisnis ini entry barrier termasuk yang rendah. Selain itu, pengembangan produk atau inovasi produk menjadi permasalahan pada Monica Collection Semarang. Banyak pesaing yang terus mengembangkan produk baru, baik desain, corak, model maupun jenis kain yang digunakan. Selain itu perubahan selera konsumen juga menjadi peluang sekaligus juga tantangan bagi penciptaan produk baru.

Strategi (Strategy) merupakan sebuah rencana tindakan dari sebuah organisasi untuk mencapai misi. Masing-masing area fungsional memiliki sebuah strategi untuk mencapai misinya dan untuk membantu organisasi mencapai misi keseluruhan (dimana ada tiga cara konseptual mencapai misi: diferensiasi, kepemimpinan biaya dan respons). Dalam hal ini area fungsional untuk strategi operasi terkait dengan sepuluh kebijakan/keputusan operasi. (Heizer dan Render, 2015).

Sepuluh keputusan operasi meliputi produk meliputi kustomisasi/standarisasi produk dan durabilitas/ketahanan dari produk tersebut. Kualitas: menjelaskan ekspektasi kualitas dari pelanggan dan bagaimana cara mencapainya. Proses, meliputi disain fasilitas, kapasitas, seberapa banyak yang diotomatisasi. Lokasi berhubungan dengan pemasok yang dekat/pelanggan yang dekat. Tata Ruang : sel kerja/lini perakitan. Sumber Daya Manusia : spesialisasi atau pengayaan pekerjaan. Rantai Pasokan: pemasok tunggal atau jamak. Persediaan : kapan melakukan pemesanan kembali, seberapa banyak yang 
harus disiapkan. Penentuan Jadwal : tingkat produksi yang stabil atau berfluktuasi. Pemeliharaan : perbaikan seperti yang diperukan atau pemeliharaan preventif. (Heizer dan Render, 2015).

\section{Keunggulan Bersaing}

Strategi adalah bagaimana sebuah organisasi diharapkan mencapai misi dan tujuannya. Strategi khusus dalam manajemen operasi terdiri dari deferensiasi, kepemimpinan dalam biaya dan respons. Diferensiasi merupakan penilaian strategi khusus dari diferensiasi meliputi disain inovatif, lini produk yang luas, jasa purna jual, pengalaman. Kepemimpinan dalam Biaya meliputi kepemimpinan biaya strategi khusus bisa dilihat dari biaya overhead yang kecil, penggunaan kapasitas yang efektif, manajemen persediaan. Respons merupakan strategi khusus berkaitan dengan fleksibilitas, keandalan, kecepatan. (Heizer dan Render, 2015).

Keunggulan kompetitif secara tidak langsung menyatakan penciptaan sebuah sistem yang memiliki sebuah keunggulan yang berbeda dengan pesaingnya. Keunggulan bersaing bisa tercapai melalui diferensiasi, biaya rendah dan respons. Beberapa sumber kajian adalah terkait strategi bersaing dan core capability diambil dari Mochammad (2016) yang meneliti konfeksi scissors Surabaya dan Madziatul (2018) terkait konfeksi dan bordir Arvfad di Malang.

\section{Kerangka Pikir}

Kerangka pikir penelitian ini menjelaskan keunggulan bersaing yang dipersepsikan Monica Collection yaitu biaya rendah. Selanjutnya berdasar keunggulan bersaing yang dipersepsikan tersebut diidentifikasi bagaimana sepuluh kebijakan operasi yang diterapkan selama ini. Hasil identifikasi ini kemudian dikaji kesesuaiannya dengan strategi khusus atau strategi operasi. Strategi khusus atau strategi operasi berdasarkan terapan kebijakan operasi tersebut bisa satu jenis strategi atau lebih.

Berdasarkan strategi khusus atau strategi operasi ini selanjutnya dievaluasi kesesuaiannya dengan keunggulan bersaing yang dipersepsikan Monica Collection yaitu Biaya rendah. Perbaikan dan pengembangan dalam sepuluh kebijakan operasi yang diterapkan Monica. Namun bila tidak sesuai ada kemungkinan lebih mengarah kepada 
keunggulan bersaing diferensiasi atau respon cepat. Dengan demikian akan diberikan alternatif rekomendasi apakah perlu mengubah keunggulan bersaingnya, atau melakukan penyesuaian terhadap penerapan 10 (sepuluh) kebijakan operasinya agar dapat mendukung pencapaian keunggulan bersaing biaya rendah.

\section{Definisi Operasional Variabel}

Keunggulan bersaing biaya rendah merupakan keunggulan bersaing dalam persaingan industri pakaian anak dan bayi yang dipersepsikan Monica Collection Semarang. Keunggulan bersaing biaya rendah ini merupakan keunggulan bersaing yang mendasarkan biaya yang efisien. Dalam penelitian ini biaya tersebut dibatasi pada biaya yang terkait dengan system operasi produk pakaian anak dan bayi yang dihasilkan Monica Collection Semarang.

Keunggulan bersaing diferensiasi merupakan keunggulan bersaing dalam persaingan industry pakaian anak dan bayi berupa keunggulan khas yang tidak mudak mudah ditiru oleh pesaing produk pakaian anak dan bayi. Keunggulan khas ini dapat melekat pada spesifikasi fisik produk pakaian anak dan bayi, kemasan, cara penyampaian, dan penempatnnya.

Keunggulan bersaing respon cepat merupakan keunggulan bersaing dalam persaingan isdustri pakaian anak dan bayi yang dapat menyajikan produk tersebut kepada konsumen dalam hal kecepatan dan ketepatan waktu penyampaian, temapt penyampaian dan rancangan fisik produk pakaian anak dan bayi yang memenuhi kebutuhan dan keinginan segmen pasar yang dilayani.

Strategi Operasi atau strategi khusus merupakan strategi fungsional manajemen operasi yang berupa: Fleksibilitas, merupakan strategi operasi yang dapat dengan relative mudah untuk menyesuaikan perubahan selera segmen pasar produk pakaian anak dan bayi terkait dengan penyesuaian dalam unsur-unsur system operasi Monica Collection Semarang. Harga rendah merupakan strategi operasi dalam hal penetapan harga jual produk pakaian anak dan bayi yang dipersepsikan relative lebih rendah disbanding produk sejenis dari para pesaingnya. 
Pengiriman merupakan strategi operasi kecepatan dan ketepatan waktu penyampaian produk pakaian anak dan bayi kepada konsumen baik secara langsung maupun melalui pedagang penyalurnya. Selain itu indikator yang digunakan untuk mengukur strategi ini adalah ketepan waktu rancangan dan produksi pakaian anak dan bayi sesuai kebutuhan dan keinginan segmen pasarnya. Kualitas merupakan strategi operasi yang dukur dari penetapan standar spesifikasi kinerja produk pakaian anak dan bayi yang dapat disesuaikan dengan semua unsur dalam system operasinya. Layanan purna jual merupakan strategi yang menekankan pada upaya untuk menjaga loyalitas konsumen pakaian anak dan bayi yang diukur dengan hasil yang berupa pembelian ulang dari konsumen dan positive word of mouth. Lini produk yang luas merupakan strategi operasi yang memfokuskan pada ragam atau varian produk pakaian anak dan bayi namun masih berada dalam satu lini produk yang sama.

Kebijakan Operasi merupakan aktivitas operasional dalam fungsi manajemen operasi di sepanjang lini system operasi yang mencakup: Perancangan produk, yaitu perancangan produk pakaian anak dan bayi yang diukur dari rancangan bentuk (model), jenis, warna, dan ukuran sesuai dengan segmen pasarnya. Kualitas merupakan standar kinerja produk pakaian anak dan bayi yang sesuai dengan spesifikasi yang diformulasikan dalam rancangan yang juga diukur dari kesesuaian bentuk (model), jenis, warna, dan ukuran yang sesuai dengan segmen pasarnya. Perancangan proses dan kapasitas yaitu keberadaan jumlah mesin dan peralatan produksi yang digunakan untuk menghasilkan produk pakaian anak dan bayi yang diukur dari tingkat efisiensi dan efektivitasnya. Pemilihan lokasi metupakan tempat berdirinya bangunan fisik Monica Collection Semarang yang digunakan untuk memproduksi pakaian anak dan bayi, yang diukur dari kemudahan akses pengadaan bahan baku kain dan bahan pendukungnya, serta distribusi produk pakaian anak dan bayi.

Perancangan tata letak merupakan penataan seluruh ruang produksi yang digunakan untuk menghasilkan produk pakaian anak dan bayi mencakup gudang bahan kain dan bahan pendukung, lantai pabrikasi dan tempat pengemasan, serta seluruh mesin jahit, obras, mesin lain dan peralatan yang diperlukan. Sumber Daya Manusia (SDM) dan rancangan pekerjaan merupakan spesifisikasi tenaga kerja langsung untuk memproduksi 
pakaian anak dan bayi dengan seluruh rincian tugas dan tanggung jawab untuk setiap jenis pekerjaan. Manajemen rantai pasokan merupakan system pada Monica Collection Semarang untuk mengelola arus informasi, arus keuangan, arus persediaan kain dan bahan pendukung di seluruh lini system operasi. Persediaan merupakan pengelolaan bahan baku kain yang optimal yang diukur dari tatl biaya persediaan yang efisien meliputi biaya penyimpanan daan biaya pemesanan.

Penjadualan merupakan rincian pengaturan waktu produksi pakaian anak dan bayi yang ditentukan oleh kapasitas mesin jahit, obras, dan mesin lainnya, serta peralatan lainnya, dan ketersediaan kuantitas dan kapasitas tenaga kerja langsung serta ketersediaan bahan kain dan bahan pendukung lainnya. Pemeliharaan merupakan kegiatan untuk mengelola keberadaan fasilitas produksi yang berupa mesin jahit, mesin obras, serta mesin lainnya dan juga peralatan yang digunakan untuk memproduksi pakaian anak dan bayi baik pendegahan maupun perbaikan. Indikator lain yang digunakan untuk mengukur adalah upaya untuk menjaga kesetiaan konsumen yang melakukan pembelian ulang produk pakaian anak dan bayi serta positive word of mouth.

\section{METODE PENELITIAN}

Penelitian ini menggunakan responden pemilik selaku pimpinan perusahaan, kepala bagian produksi, kepala bagian kualitas, kepala bagian sebagai sumber data penelitian. Data penelitian menggunakan jenis data primer dan data sekunder. Data primer diperoleh langsung dari sumber data (responden), sedangkan data sekunder diperoleh dari catatan perusahaan.

Data primer meliputi data design produk yang meliputi model, ukuran, warna. Data proses produksi yang dilakukan untuk membuat baju bayi dan anak. Data pembelian (pengadaan) bahan baku. Data tentang distrinbusi bahan baku dan barang jadi.Data tentang kebutuhan dan persyaratan tenaga kerja. Data terkait persediaan bahan baku, barang dalam proses, dan barang jadi. Data tentang produk cacat dan perlakuannya. Data produksi dan kapasitas produksi. Data tentang fasilitas produksi/maintenance (program maintenance, breakdown mesin, cara penanganan kerusakan mesin). Data terkait dengan kondisi dan lingkungan kerja 
Data sekunder dalam penelitian ini meliputi: Data jenis produk yang dihasilkan. Data jenis bahan baku dan bahan penolong. Data biaya (biaya bahan baku dan penolong, biaya-biaya terkait dengan persediaan; biaya tenaga kerja langsung; biaya transportasi). Data kebutuhan bahan baku dan bahan penolong. Jumlah dan jenis mesin yang digunakan dalam proses produksi. Data jumlah pemesanan (permintaan). Data waktu proses produksi. Data waktu operasi yang tersedia untuk produksi. Data layout perusahaan. Data harga jual produk. Data tentang suplier dan distributor. Data jumlah karyawan.

Teknik pengumpulan data menggunakan beberapa cara yaitu: survey pustaka yaitu Catatan atau laporan produksi perusahaan. Wawancara . Obervasi. Teknik analisis data menggunakan deskriptif kualitatif dan metode kuantitatif.

\section{HASIL DAN PEMBAHASAN \\ Perancangan/Pengembangan produk}

Berikut akan diuraiakan tahapan pengembangan produk pada Monica Collection. Mengambil contoh salah satu produk baru yang dikembangkan, yaitu produk bantal dan guling bayi. Produk ini berada pada fase kedewasaan (maturity). Pada fase ini produk sudah optimal. Pada fase inipun banyak pesaing yang terus muncul dengan menghasilkan produk sejenis dan diferen (lebih unggul) dari segi kualitas maupun desain produk. Oleh karena itu perlu adanya inovasi dalam pengembangan produk ini. Inovasi yang terus dilakukan pada produk bantal dan guling bayi adalah inovasi pada model dan desain (corak, warna). Inovasi yang dilakukan adalah (1) bantal leher menyusui bayi, (2) bantal dot susu bayi dan (3) guling bayi karakter.

Tahapan pengembangan produk yang dilakukan oleh Monica Collection untuk mengembangkan ketiga jenis produk baru tersebut:

1) Fase Perencanaan. Pada fase perencanaan ini Monica Collection ketika akan mengembangkan produk baru mencari berbagai macam sumber ide. Ide pengembangan produk baru berasal dari faktor eksternal perusahaan yaitu dari keluhan dan masukan konsumen atau pelanggan. Dalam tahap perencanaan ini konsumen dan pelanggan memebrikan usulan produk bantal dan guling bayi yang multifungsi seperti 
bantal leher menyusui bayi, bantal dot susu bayi dan guling bayi karakter. Ketiga jenis produk tersebut memiliki fungsi utama untuk menyeimbangankan tekanan kepala bayi secara merata dan melindungi kepala dan leher bayi. Selain itu juga mempunyai fungis tambahan yaitu dapat digunakan khusus pada kegiatan menyusui dan memberikan dot. Selain itu juga untuk memberikan kemudahan bagi bayi, misalnya saat bayi duduk di kereta dorong atau sebagai alas tidur bayi dan dapat digunakan pada boks bayi serta kereta bayi. Selain itu guling dengan desain karakter membuat konsumen atau pelanggan tidak merasa bosan..

2) Fase Pengembangan Konsep. Setelah tahap perencanaan, langkah selanjutnya yang dilakukan adalah pengembangan konsep. Pada tahap ini Monica Collection membuat desain yang memiliki dua pegangan melengkung untuk di jadikan pegangan tangan bayi dan terdapat kantong sebagai pegangan penahan botol susu dengan penutup transparan. untuk mengembangkan produk supaya produk tersebut memiliki manfaat dan berbeda dari produk sebelumnya.

Berikut adalah bentuk desain produk bantal leher menyusui bayi, bantal dot susu bayi dan guling bayi karakter yang dilakukan dalam pengembangan produk.
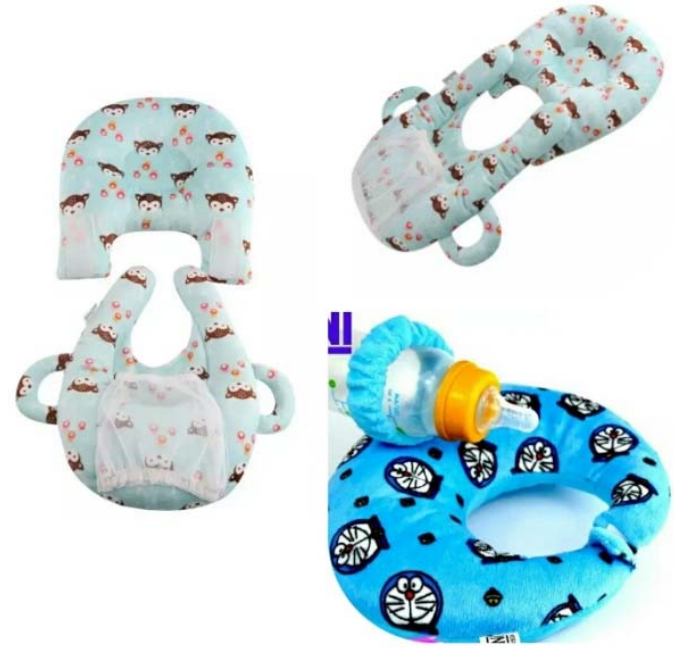

Gambar .1 Produk Bantal dan Guling Bayi

Sumber : Grace (2019) 
3) Perancangan Rinci. Setelah melakukan pengembangan konsep, langkah berikutnya adalah perancangan rinci. Perancangan rinci ini dimaksudkan untuk mengetahui secara rinci bahan baku (material kain, dakron) yang digunakan, jumlah dan kebutuhan bahan setiap produk, urutan tahapan proses produksi, waktu yang dibutuhkan setiap jenis produk, ukuran produk, sehingga akan dapat diketahui ongkos produksi guna menentukan penetapan harga per unit produk. Tahap perancangan rinci ini dilakukan dengan cara membuat Prototipe produk. Berdasarkan uraian yang telah diungkapkan oleh pemilik usaha, bahan baku yang dibutuhkan dalam pengembangan produk bantal dan guling bayi yaitu berupa kain katun, dakron, yang ukuran 45x27x5 cm / 17x10x1,97 inci. Untuk ketiga jenis produk ini menggunakan bahan baku kain yaitu katun jepang. Hal ini yang menjadikan perbedaan dari produk yang dihasilkan oleh Monica Collection dengan poduk jenis lainnya. Pada produk yang lain Monica Coleection menyediakan tiga jenis kain yang dapat di pilih oleh pelanggan maupun konsumen dengan varian harga yang berbeda sesuai dengan kualitas kain tersebut.

4) Peluncuran Produk. Sebelum produk diproduksi massal dan diluncurkan ke pasar, ada tahap evaluasi untuk melihat kembali prototipe yang dibuat. Salah satu hasil evaluasi pada pembuatan prototipe produk adalah pada saat proses produksi kendala yang timbul adalah jahitan yang kurang rapi atau jahitan terbuka dan kemacetan pada mesin jahit.

Monica Collection sebagai sebuah industri yang berdasarkan ukurannya masih kategori industri rumah tangga atau skala mikro, meskipun demikian pada saat melakukan kegiatan pengembangan produk sudah melakukan beberapa tahapan pengembangan produk. Sebagai contoh pada saat tahap pengembangan produk baru untuk bantal dan guling bayi dengan fungsi tambahan yaitu mempermudah pada saat proses menyusui dari ASI maupun susu tambahan (dot bayi), Monica Collectin mendapatkan ide pengembangan produk dari konsumen. Artinya bahwa adanya kesadaran untuk terus mengikuti perubahan selera konsumen. Hal ini tentu saja penting bagi perusahaan untuk terus dapat bertahan hidup dengan cara terus mengembangkan produk baru dan terutama sumber ide pengembangan produk dari konsumen. 
Pada tahap perancangan konsep, Monica Collection sudah membuat prototipe sebelum akhirnya produk tersebut diproduksi massal. Dengan demikian perusahaan dapat mengetahui dengan lebih rinci akan tahapan proses produksi untuk produk baru tersebut, mengetahui jumlah dan jenis kebutuhan bahan, lama waktu proses per unit produknya. Sehingga biaya produksi per unit dapat diketahui dan diperkirakan. Hal ini tentu saja sebagai informasi dan bahan evaluasi tentang pengembangan produk baru. Untuk mendukung Low Cost Strategy yang menjadi keunggulan bersaing perusahaan, Monica Collection ketika pembuatan produk memberikan berbagai alternatif dan mengurangi tahapan proses yang tidak perlu. Sehingga biaya produksi per unit dapat ditekan, terutama biaya tenaga kerja langsung per unit dan biaya energi (listrik) per unit.

Selain itu untuk mendukung Low Cost Strategy setiap prototipe yang dikembangkan dievaluasi kendala teknis, misalkan pengidentifikasian peluang munculnya produk cacat. Hal ini dilakukan untuk mengurangi atau meminimalkan produk cacat pada saat proses produksi massal (proses produksi berlangsung). Dengan mengetahui jenis produk cacat berikut dengan penyebab produk cacat, maka perusahaan dapat segera melakukan perbaikan proses dan melakukan improvement pada penyebab kerusakan produk. Mengapa hal ini mendukung strategi baiaya rendah? Sebab setiap produk yang cacat didalamnya ada biaya bahan baku, biaya tenaga kerja langsung dan biaya energi. Selain itu jika produk masih bisa di re-work tentu saja hal ini akan menamabah biaya. Oleh akrena itu dengan melakukan pengendalian produk cacat, maka biaya lebih efisien dan lebih produkstif. Hal inilah yang kemudian keputusan pengembangan produk ini juga mendukung keunggulan bersaing perusahaan, yaitu Low Cost.

\section{Kualitas}

Penelitian yang dilakukan pada Monica Collection, ditemukan cukup tingginya cacat produk pada beberapa produk yang terdapat pada Perusahaan Monica Collection. Permasalahan kualitas khususnya cacat produk pada produk gendongan samping. Berikut data yang diberikan perusahaan terkait jumlah produksi, jumlah produk cacat dan persentase produk cacat sebagai berikut : 
Tabel 1.

Data Jumlah Produksi, Jumlah Produk Cacat, dan Persentase Produk Cacat Produk Gendongan Samping pada Perusahaan Monica Collection Bulan Januari 2019

\begin{tabular}{l|c|c|c}
\hline \multicolumn{4}{|c}{ Data Bulan Januari } \\
\hline $\begin{array}{c}\text { Periode } \\
\text { Pengamatan }\end{array}$ & $\begin{array}{c}\text { Jumlah } \\
\text { Produksi }\end{array}$ & $\begin{array}{c}\text { Jumlah Produk } \\
\text { Cacat }\end{array}$ & Persentase Produk Cacat \\
\hline Minggu I & 35 & 4 & $11 \%$ \\
\hline Minggu II & 20 & 2 & $10 \%$ \\
\hline Minggu II & 25 & 3 & $12 \%$ \\
\hline Minggu IV & 30 & 3 & $10 \%$ \\
\hline & 110 & 12 & $11 \%$ \\
\hline
\end{tabular}

Sumber : Rivaldo (2019)

Berdasarkan data tabel 2, rata-rata persentase jumlah produk cacat pada bulan Januari dan Febuari 2019 yaitu sebesar 11\% dan 13\%. Persentase tersebut melewati jumlah toleransi cacat produk yang telah ditetapkan oleh perusahaan yaitu $9 \%$.

Tabel 2

Data Jumlah Produksi, Jumlah Produk Cacat, dan Persentase Produk Cacat Produk Gendongan Samping pada Perusahaan Monica Collection

Bulan Febuari 2019

\begin{tabular}{l|c|c|c}
\hline \multicolumn{4}{c}{ Data Bulan Febuari } \\
\hline $\begin{array}{c}\text { Periode } \\
\text { Pengamatan }\end{array}$ & Jumlah Produksi & $\begin{array}{c}\text { Jumlah Cacat } \\
\text { Produk }\end{array}$ & $\begin{array}{c}\text { Presentase Produk } \\
\text { Cacat }\end{array}$ \\
\hline Minggu I & 30 & 4 & $13 \%$ \\
\hline Minggu II & 45 & 6 & $13 \%$ \\
\hline Minggu II & 25 & 3 & $12 \%$ \\
\hline Minggu IV & 40 & 5 & $13 \%$ \\
\hline & 140 & 18 & $13 \%$ \\
\hline
\end{tabular}

Sumber : Rivaldo (2019) 
Berkaitan dengan kualitas, beberapa permasalahan produk cacat dalam produk gendongan samping yaitu :Penyambungan lengan yang tidak baik dan mudah lepas, Jahitan ring yang tidak kuat, Kain kotor, Jahitan benang tidak rapi, dan Dakron yang mudah keluar dari gendongan

Selanjutnya untuk melihat sejauh mana produk yang dihasilkan memenuhi kebutuhan spesifikasi pelanggan, peneliti melakukan analisa dengan menggunakan metode six sigma dan perhitungan DPMO. Dari hasil analisis, peneliti menganalisis ratarata untuk rata-rata DPMO dan Six Sigma pada bulan Januari dan Febuari yaitu dengan six sigma 2,23 dan DPMO 230000. Dengan batas toleransi kecacatan 9\% memiliki nilai sigma 2,41 dengan DPMO 180000 per sejuta produk. Dari perbandingan dapat disimpulkan Perusahaan Monica Collection masih belum mencapai nilai sigma yang diharapkan, sehingga masih perlu adanya perbaikan yang harus dilakukan. Perbaikan yang dilakukan harus secara terus- menerus hingga mencapain nilai 6 $\sigma$ (Six Sigma).

Peneliti juga perlu melihat produk yang dihasilkan pada monica collection apakah produk gendongan samping masih dalam batas control limit.

Tabel 3

Peritungan P Chart (Peta Kendali)

\begin{tabular}{ccccccc}
\hline $\begin{array}{c}\text { Periode Pengamatan } \\
\text { (Minggu) }\end{array}$ & $\begin{array}{c}\text { Jumlah } \\
\text { Produksi }\end{array}$ & $\begin{array}{c}\text { Jumlah Produk } \\
\text { Cacat }\end{array}$ & Proporsi & UCL & LCL & CL \\
\hline I & 35 & 4 & 0.1143 & 0.16 & 0.079 & 0,12 \\
\hline II & 20 & 2 & 0.1 & 0.16 & 0.079 & 0,12 \\
\hline III & 25 & 3 & 0.12 & 0.16 & 0.079 & 0,12 \\
\hline IV & 30 & 3 & 0.1 & 0.16 & 0.079 & 0,12 \\
\hline V & 30 & 4 & 0.1333 & 0.16 & 0.079 & 0,12 \\
\hline VI & 45 & 6 & 0.1333 & 0.16 & 0.079 & 0,12 \\
\hline VII & 25 & 3 & 0.12 & 0.16 & 0.079 & 0,12 \\
\hline VIII & 40 & 5 & 0.125 & 0.16 & 0.079 & 0,12 \\
\hline Rata-rata & 31.25 & 3.75 & 0.1182 & 0.16 & 0.079 & 0,12 \\
\hline
\end{tabular}

Sumber : Rivaldo (2019) 


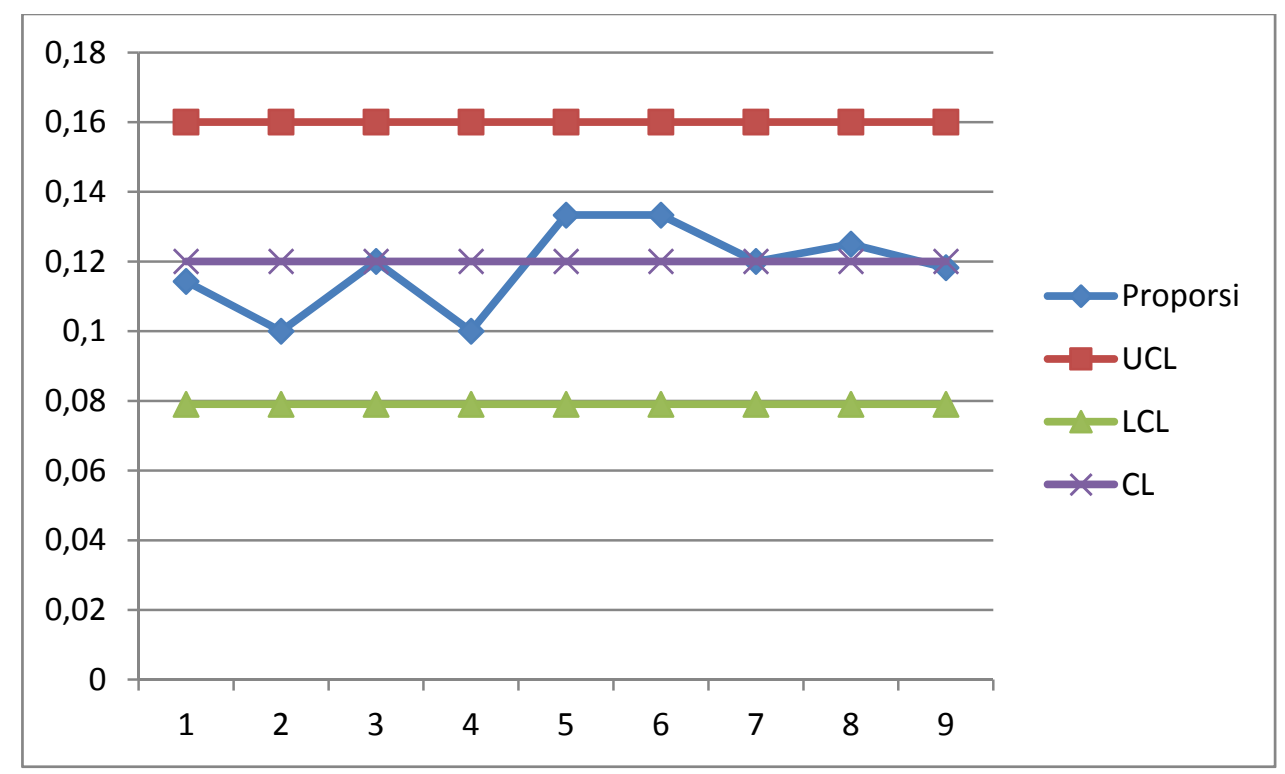

Gambar 2 Grafik Peta Kendali P

Sumber : Rivaldo (2019)

Dari grafik peta kendali P diatas dapat disimpulkan bahwa pada produk gendongan samping selama 8 minggu bulan Januari dan Febuari 2019 hasil produksi pada perusahaan Monica Collection masih dalam batas kendali. Hal ini dapat terlihat dalam 8 minggu proporsi pada gendongan samping tidak ada yang melebihi garis batas kendali atas. Tetapi walaupun demikian pada hasil perhitungan DPMO yang dikonversi ke nilai Sigma Perusahaan Monica Collection masih mendapatkan nilai sebesar 2,23 dengan rata- rata cacat produk yang dihasilkan pada bulan Januari mencapai 11\% dan Febuari sebesar 13\% hal ini melebihi batas toleransi yang telah ditetapkan oleh perusahaan yaitu $9 \%$ dan nilai Sigma yang dihasilkan juga masih belum optimal dan belum sesuai dengan nilai Sigma yang telah ditetapkan perusahaan yaitu 2,41 sehingga Perusahaan Monica Collection masih perlu melakukan perbaikan untuk meminimilkan cacat produk pada Gendongan Samping dan mencapat batas toleransi yaitu 9\% dan dapat mencapai nilai Sigma sesuai dengan yang telah diharapkan. Perbaikan yang perlu dilakukan untuk meningkatkan kualitas gendongan samping yaitu dengan menentukan tahapan rencana untuk meningkatkan kualitas pada gendongan samping. 
Tabel 4

Perencanaan Tindakan $5 \mathrm{~W}+2 \mathrm{H}$ pada Jenis Cacat Produk Gendongan Samping

\begin{tabular}{|c|c|c|c|c|c|}
\hline \multirow{2}{*}{ Jenis } & \multirow{2}{*}{$5 \mathrm{~W}+2 \mathrm{H}$} & \multicolumn{4}{|c|}{ Deskripsi } \\
\hline & & Manpower & Manpower & Manpower & Manpower \\
\hline $\begin{array}{l}\text { Tujuan } \\
\text { Utama }\end{array}$ & What (Apa)) & $\begin{array}{l}\text { penetapan target } \\
\text { produksi sesuai } \\
\text { dengan } \\
\text { kemampuan } \\
\text { karyawan. }\end{array}$ & $\begin{array}{l}\text { Melakukan servis/ } \\
\text { perbaikan mesin } \\
\text { secara berkala }\end{array}$ & $\begin{array}{l}\text { perbaikan layout } \\
\text { dan tata letak } \\
\text { karena tempat } \\
\text { sempit dan } \\
\text { terjadinya } \\
\text { penumpukan } \\
\text { barang }\end{array}$ & $\begin{array}{l}\text { bahan baku } \\
\text { dicek sebelum } \\
\text { produksi dan } \\
\text { pemberian palet } \\
\text { kayu }\end{array}$ \\
\hline $\begin{array}{l}\text { Alasan } \\
\text { Kegunaan }\end{array}$ & $\begin{array}{l}\text { Why } \\
\text { (Mengapa) }\end{array}$ & $\begin{array}{l}\text { karyawan dapat } \\
\text { bekerja dan ahli } \\
\text { dalam bidangnya } \\
\text { sehingga } \\
\text { mengurangi } \\
\text { produk cacat dari } \\
\text { gendongan } \\
\text { samping }\end{array}$ & $\begin{array}{l}\text { Agar mesin } \\
\text { diperbaiki secara } \\
\text { optimal sebelum } \\
\text { terjadinya } \\
\text { kerusakan, sehingga } \\
\text { tidak mengganggu } \\
\text { jalannya proses } \\
\text { produksi }\end{array}$ & $\begin{array}{l}\text { karyawan dapat } \\
\text { bekerja lebih } \\
\text { efesien dan efektif. } \\
\text { nyaman dalam } \\
\text { melakukan } \\
\text { proses produksi }\end{array}$ & $\begin{array}{l}\text { Agar dapat } \\
\text { mengurangi } \\
\text { terjadinya kain } \\
\text { kotor yang } \\
\text { disebabkan dari } \\
\text { kain bahan } \\
\text { baku }\end{array}$ \\
\hline Lokasi & $\begin{array}{l}\text { Where } \\
\text { (Dimana) }\end{array}$ & $\begin{array}{l}\text { Perusahaan } \\
\text { Monica Collection }\end{array}$ & $\begin{array}{l}\text { Perusahaan Monica } \\
\text { Collection }\end{array}$ & $\begin{array}{l}\text { Perusahaan Monica } \\
\text { Collection }\end{array}$ & $\begin{array}{l}\text { Perusahaan } \\
\text { Monica } \\
\text { Collection }\end{array}$ \\
\hline Urutan & $\begin{array}{l}\text { When } \\
\text { (Kapan) }\end{array}$ & $\begin{array}{l}\text { Dilakukan setiap } \\
\text { bulan pada saat } \\
\text { sebelum } \\
\text { melakukan } \\
\text { produksi }\end{array}$ & $\begin{array}{l}\text { Dilakukan } \\
\text { pengecekan mesin } \\
\text { setiap hari dan } \\
\text { servis per bulan } \\
\text { sekali }\end{array}$ & $\begin{array}{l}\text { Dilaksanakan } \\
\text { sebelum proses } \\
\text { produksi dan } \\
\text { bersifat situasional }\end{array}$ & $\begin{array}{l}\text { Dilakukan } \\
\text { sebelum proses } \\
\text { produksi }\end{array}$ \\
\hline Metode & $\begin{array}{l}\text { How } \\
\text { (Bagaimana) }\end{array}$ & & $\begin{array}{l}\text { Operator Jahit dan } \\
\text { Obras melakukan } \\
\text { pengecekan mesin } \\
\text { jahit. }\end{array}$ & $\begin{array}{l}\text { Pemilik } \\
\text { Perusahaan } \\
\text { malakukan } \\
\text { perbaikan layout } \\
\text { dan menempatkan } \\
\text { tempat pada bagian } \\
\text { setiap proses }\end{array}$ & $\begin{array}{l}\text { memotong kain } \\
\text { yang terdapat } \\
\text { noda atau kain } \\
\text { kotor karena } \\
\text { penumpukan } \\
\text { bahan baku }\end{array}$ \\
\hline Manfaat & $\begin{array}{l}\text { How much } \\
\text { (Berapa) }\end{array}$ & $\begin{array}{l}\text { Diharapkan } \\
\text { karyawan dapat } \\
\text { paham dan } \\
\text { terampil dalam } \\
\text { melakukan } \\
\text { penjahitan } \\
\text { penyambungan } \\
\text { lengan dan } \\
\text { melakukan proses } \\
\text { produksi sesuai } \\
\text { dengan intruksi }\end{array}$ & $\begin{array}{l}\text { Manfaat yang } \\
\text { didapat adalah } \\
\text { mesin tidak mudah } \\
\text { rusak dan tidak } \\
\text { menggangu proses } \\
\text { produksi }\end{array}$ & $\begin{array}{l}\text { Karyawan akan } \\
\text { merasa lebih } \\
\text { berkonsentrasi } \\
\text { dengan kondisi } \\
\text { atau lingkungan } \\
\text { kerja yang baru }\end{array}$ & $\begin{array}{l}\text { bahan baku dan } \\
\text { pemotongan } \\
\text { dicek yang } \\
\text { kotor dapat } \\
\text { dikurangi pada } \\
\text { proses produksi }\end{array}$ \\
\hline
\end{tabular}




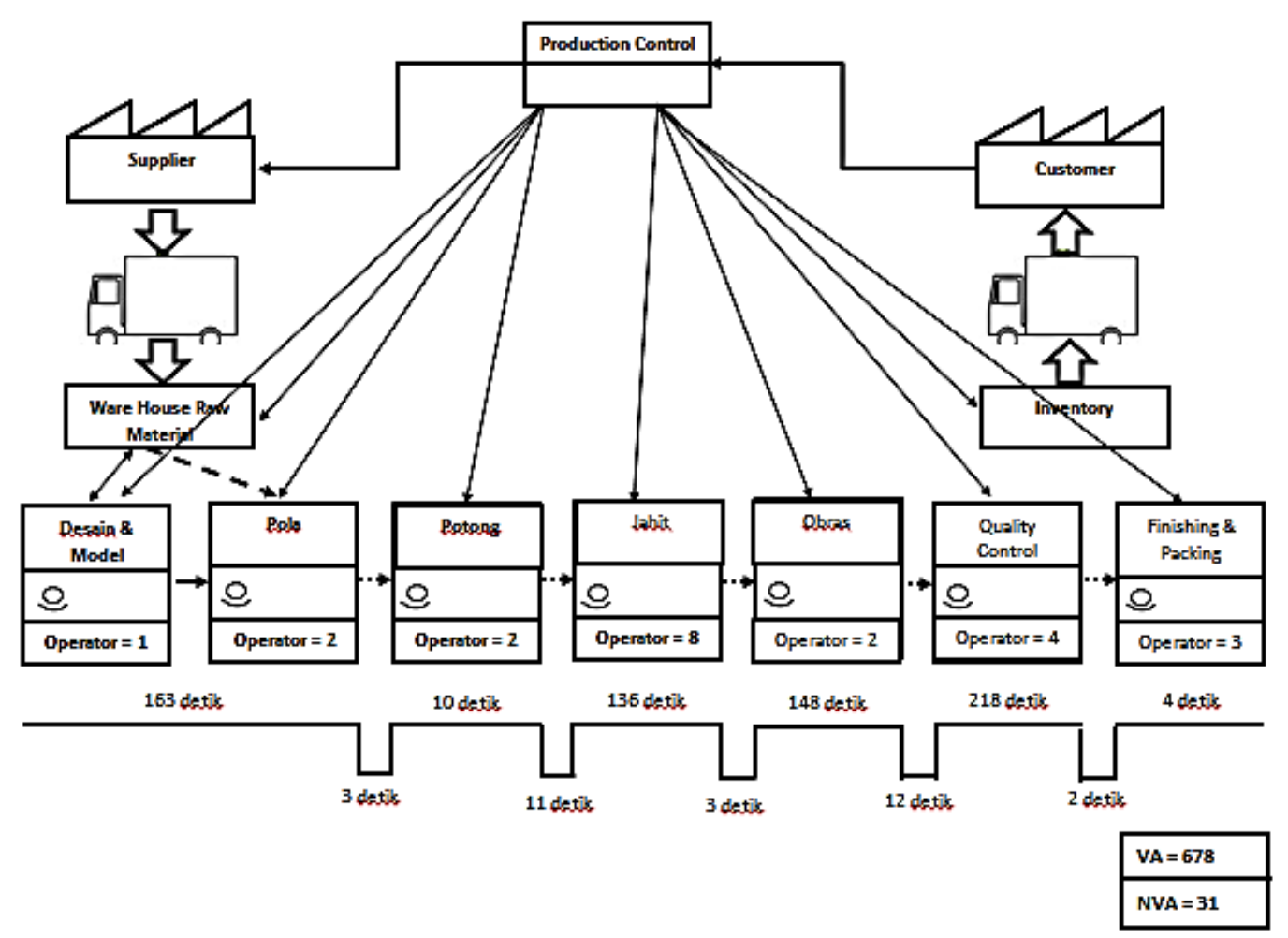

Gambar 3

Big Picture Mapping Monica Collection

Sumber : Prasetyo (2019)

Process Activity Mapping Tas Mini pada Monica Collcetion

SUBYEK YANG DIBUAT DIAGRAM

TANGGAL :28 / 02 / 2019

Bagian Departemen Produksi Tas Mini Monica Collection

\begin{tabular}{|c|c|c|c|c|c|}
\hline No & $\begin{array}{l}\text { Jarak Tempuh } \\
\text { Dalam Meter }\end{array}$ & $\begin{array}{c}\text { Waktu Dalam } \\
\text { Detik }\end{array}$ & Simbol Diagram & Deskripsi Proses & Keterangan \\
\hline 1 & 0 & 0 & & $\begin{array}{l}\text { mengambil bahan } \\
\text { baku } 1 \text { roll kain }\end{array}$ & NVA \\
\hline 2 & 0 & 240 & & $\begin{array}{l}\text { pengecekan } \\
\text { terhadap bahan }\end{array}$ & NNVA \\
\hline 3 & 3 & 10 & & $\begin{array}{l}\text { memindahkan } \\
\text { bahan baku }\end{array}$ & NNVA \\
\hline 4 & 0 & 40 & & $\begin{array}{l}\text { mempersiapkan } \\
\text { bahan kain } 1\end{array}$ & VA \\
\hline
\end{tabular}


JEMAP: Jurnal Ekonomi, Manajemen, Akuntansi, dan Perpajakan

\begin{tabular}{|c|c|c|c|c|c|}
\hline 5 & 0 & 10 & P & $\begin{array}{l}\text { memotong } \\
\text { ukuran kain yang }\end{array}$ & VA \\
\hline 6 & 0 & 350 & & $\begin{array}{l}\text { pembuatan pola } \\
\text { dengan mal }\end{array}$ & VA \\
\hline 7 & 0 & 8 & & pengecekan pola & NNVA \\
\hline 8 & 1 & 2 & & $\begin{array}{l}\text { memindahkan ke } \\
\text { pemotongan }\end{array}$ & NNVA \\
\hline 9 & 0 & 132 & & pemotongan pola & VA \\
\hline 10 & 9,2 & 10 & & $\begin{array}{l}\text { memindahkan ke } \\
\text { penjahitan }\end{array}$ & NNVA \\
\hline 11 & 0 & 250 & & $\begin{array}{l}\text { menunggu giliran } \\
\text { penjahitan }\end{array}$ & NVA \\
\hline 12 & 0 & 302 & & proses penjahitan & VA \\
\hline 13 & 0 & 23 & & pengecekan & NNVA \\
\hline 14 & 16,8 & 13 & & $\begin{array}{l}\text { memindahkan } \\
\text { bahan baku ke }\end{array}$ & NNVA \\
\hline 15 & 0 & 307 & & $\begin{array}{l}\text { menunggu giliran } \\
\text { pengisian }\end{array}$ & NVA \\
\hline 16 & 0 & 274 & & $\begin{array}{l}\text { mengambil bahan } \\
\text { baku dakron }\end{array}$ & NVA \\
\hline 17 & 0 & 43 & & pengisian dakron & VA \\
\hline 18 & 16,8 & 11 & & $\begin{array}{l}\text { memindahkan ke } \\
\text { penjahitan }\end{array}$ & NNVA \\
\hline 19 & 0 & 342 & & $\begin{array}{l}\text { menunggu giliran } \\
\text { penjahitan }\end{array}$ & NVA \\
\hline 20 & 0 & 7 & & $\begin{array}{l}\text { penjahitan } \\
\text { lubang dakron }\end{array}$ & VA \\
\hline 21 & 11,1 & 8 & & $\begin{array}{l}\text { memindahkan ke } \\
\text { bagian finishing }\end{array}$ & NNVA \\
\hline 22 & 0 & 253 & & $\begin{array}{l}\text { mengabil belt } \\
\text { dan ring }\end{array}$ & NVA \\
\hline 23 & 0 & 8 & & $\begin{array}{l}\text { pemasangan ring } \\
\text { dan belt }\end{array}$ & VA \\
\hline 24 & 0 & 12 & & pengecekan & NNVA \\
\hline 25 & 1 & 2 & & $\begin{array}{l}\text { memindahkan ke } \\
\text { bagian packing }\end{array}$ & NNVA \\
\hline 26 & 0 & 165 & & $\begin{array}{l}\text { mengambil pack } \\
\text { dari gudang }\end{array}$ & NVA \\
\hline 27 & 0 & 6 & - & pengemasan & VA \\
\hline & 58,9 & 2828 & $\begin{array}{|llll|}9 & 7 & 4 & 6 \\
\end{array}$ & Total & \\
\hline \multicolumn{3}{|c|}{$\begin{array}{r}\text { Nilai waktu tambah : } 898 / 2828 \\
=31,75 \%\end{array}$} & $\begin{array}{l}\text { Value Added: } \\
898 \text { detik }\end{array}$ & \multicolumn{2}{|c|}{$\begin{aligned} \text { Non Value Added }: & 2828-898 \\
& =1930\end{aligned}$} \\
\hline
\end{tabular}

Gambar 4 Process Activity Mapping 
JEMAP: Jurnal Ekonomi, Manajemen, Akuntansi, dan Perpajakan ISSN: 2622-612X (Media Online) | Vol.3 | No.1 | April 2020

Pada proses produksi tas mini terdapat 27 aktivitas yang terdiri dari 9 aktivitas operasi, 7 aktivitas transportasi, 4 aktivitas inspeksi, 6 aktivitas delay, dan 1 aktivitas penyimpanan. 27 aktivitas tersebut terdapat 18 aktivias yang tidak memberi nilai tambah. Persentase proses yang memberi nilai tambah hanya $31,75 \%$ atau sebanyak 898 detik saja dari total keseluruhan proses produksi. Artinya terdapat 68,25\% atau 1930 detik kegiatan yang tidak memberikan nilai tambah pada proses produksi tas mini.

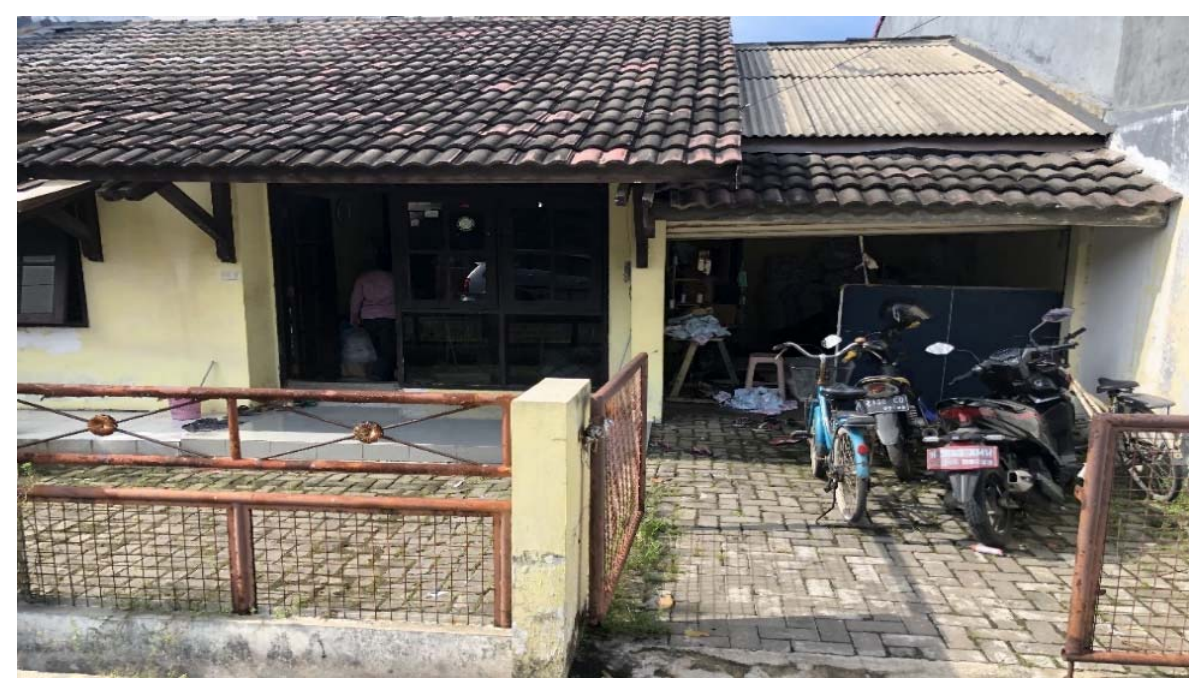

Gambar 5

Tampak Depan Perusahaan Monica Collection

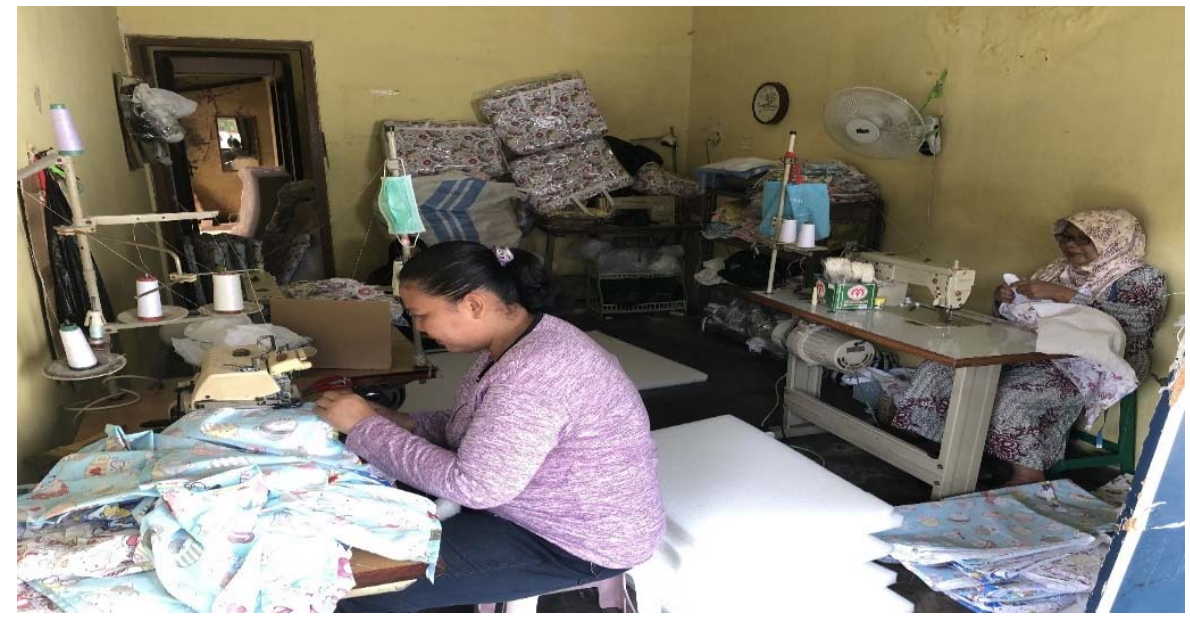

Gambar 6

Suasana Ruang Produksi Monica Collection 
JEMAP: Jurnal Ekonomi, Manajemen, Akuntansi, dan Perpajakan

Gambar di atas memperlihatkan bagaimana penataan layout dan suasana kerja pada Monica Collection, Semarang. Dimana mesin, karyawan dan bahan baku diatur sesuai dengan kelompok (fungsi). Tipe layout yang dipakai adalah tipe layout yang berorientasi pada proses, yaitu layout produksi dimana mesin, tenaga kerja dan fasilitas produksi diletakkan berdasarkan proses produksi tertentu. Untuk Monica Collection antara proses potong, jahit, proses pengisian dakron, finishing dan persediaan produk jadi diletakkan pada tempat terpisah berdasarkan fungsinya.

Berikut adalah layout produksi yang digunakan saat ini pada Monica Collection Semarang.

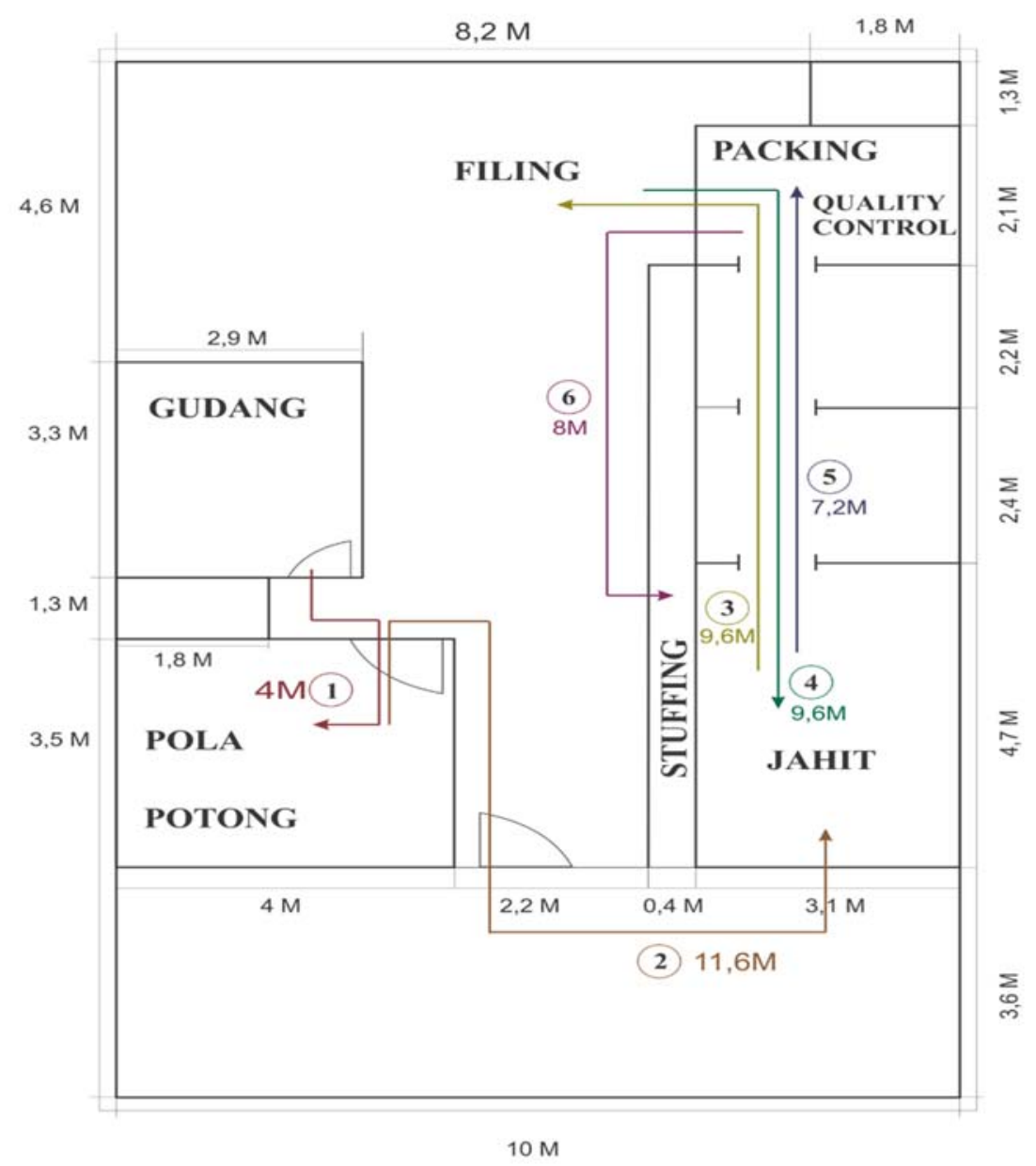

Gambar 7

Layout Monica Collection (1:1000)

Sumber : Djiantoro 


\section{PENUTUP}

\section{KESIMPULAN}

Kontribusi keputusan operasi dalam pencapaian keunggulan bersaing biaya rendah (Low Cost) pada Monica Collection Semarang adalah adanya kesadaran untuk terus mengikuti perubahan selera konsumen. Hal ini tentu saja penting bagi perusahaan untuk terus dapat bertahan hidup dengan cara terus mengembangkan produk baru dan terutama sumber ide pengembangan produk dari konsumen. Pengendalian kualitas ditemukan bahwa cacat produk yang dihasilkan pada produk gendongan samping pada perusahaan Monica Collection melebihi batas toleransi yang telah ditetapkan oleh perusahaan.

Hasil penelitian mengenai proses produksi ditemukan bahwa dalam kegiatan produksi terjadi penumpukan antrean pada tahap penjahitan dan arus track back di Monica Collection. Hal tersebut di tunjukan dari hasil process activity mapping 3 produk cacat yang terdiri dari tas mini, gendongan samping, tas bantal balita berupa lamanya kegiatan yang tidak bernilai tambah atau non value adding. Lokasi yang strategis, sehingga bisa diakses dengan mudah untuk pengiriman material. Layout yang ada pada Monica Collection masih menimbulkan gerakan yang tidak perlu dan gerakan bolak balik.

Hasil penelitian berkaitan dengan sumber daya manusia dan kapasitas yang mendukung low cost yaitu pada bagian penjahitan, karyawan perlu mempunyai ketrampilan menjahit, demikian juga bagian membuat pola dan memotong pola, butuh keahlian khusus. Penelitian yang dilakukan pada Monica Collection Semarang, terkait dengan manajemen rantai pasokan menunjukan hasil bahwa hasil penelitian yang dapat mendukung low cost karena sudah berlangganan dengan pemasok, maka biaya pemrosesan transaksi pemesanan menjadi sangat sedikit. Demikian pula untuk ekspedisi dari pemasok, karena ditanggung pemasok maka perusahaan Monica Collection tidak perlu mengeluarkan biaya untuk bahan baku yang digunakan. Hasil penelitian lain yang mendukung low costterkait dengan ekspedisi produk ke distributor menggunakan jasa pengiriman yang sangat murah. Ada penghematan sebesar Rp. 416.462,00 atau sekitar 13,34\%. Persediaan Monica Collection ditempatkan hanya untuk beberapa hari saja, sehingga biaya simpan rendah maka biaya persediaan tahunan menjadi rednah juga, sehingga bisa mendukung keunggulan kompetitif biaya rendah. 


\section{SARAN}

Karena sebagian besar dari sepuluh kontribusi keputusan operasi yang diterapkan Perusahaan Monica Collection telah mendukung pencapaian keunggulan bersaing biaya rendah (Low Cost). Maka keputusan operasi yang belum mendukung Low Cost sebaiknya perlu diperbaiki, seperti :Pengendalian kualitas masih perlu dibenahi dengan menggunakan metode six sigma agar dapat memperkecil produk cacat. Proses produksi sebaiknya menggunakan metode line balancing dan penataan lay out sehingga tidak ada alur track back. Untuk persediaan sebaiknya digunakan metode EOQ Probabilistik, sehingga akan menekan biaya penyimpanan.

\section{DAFTAR PUSTAKA}

Amanah, Dita. 2015. SWOT Analysis Of The Wildlife Park of Medan, Indonesia. International Journal Of Economics, Commerce and Management. Vol. III, Issue 10. October ; 500-509.

Angela, Shintya Ch. 2019. Analisis Manajemen Rantai Pasokan Pada Produk Bantal dan Guling Studi Kasus Home Industry Monica Collection Semarang. Skripsi. Fakultas Ekonomi dan Bisnis. Unika Soegijapranata. Semarang.

Churiyah, Madziatul, 2013. Strategi Bersaing Dan Core Capability Pada Usaha Konveksi Dan Bordir, MODERNISASI, Volume 9, Nomor 3, Oktober 2013, hal 249-257.

Djiantoro, Albert Christian. 2019. Perbaikan Tata Letak atau Lay Out Fasilitas Produksi Pada Monica Collection Semarang. Skripsi. Fakultas Ekonomi dan Bisnis. Unika Soegijapranata. Semarang.

Ebadian, M.,et.all (2009). Hierarchical Production Planning and Schedulling in Make-toorder Environments : Reaching Short and Reliable Delivery Dates. International Journal of Production Research, vol. 47, No. 20, 5761-6789.

Faruq, Ammar Muhammad dan Usman, Indriawati, 2014. Penyusunan Strategi Bisnis Dan Strategi Operasi Usaha Kecil Dan Menengah Pada Perusahaan Konveksi 
Scissors Di Surabaya, Jurnal Manajemen Teori dan Terapan Tahun 7. No. 3, Desember 2014, hal 173-198.

Fernando, Y. C., \& Noya, S., 2014. Optimasi Lini Produksi dengan Value Stream Analysis Tools. Jurnal Teknik Industri, Vol. 13, No. 2, Des 2014 hal 125-133.

Grace, Monika. 2019. Evaluasi Pengembangan Produk Alas Stroller dan Bantal Guling Bayi pada Monica Collection Semarang. Skripsi. Fakultas Ekonomi dan Bisnis. Unika Soegijapranata. Semarang.

Heizer, J., \& Render, B., 2015. Manajemen Operasi, Manajemen Keberlangsungan dan Rantai Pasokan (11 ${ }^{\text {th }}$ ed.) Jakarta : Salemba Empat.

Hernando, Galih. 2019. Analisis Pengendalian Persediaan Bahan Baku Dakron Roll dengan Metode Economic Order Quantity Probabilistik Pada Monica Collection Semarang. Skripsi. Fakultas Ekonomi dan Bisnis. Unika Soegijapranata. Semarang. Hines, P., \& Rich, N. 1997. Emerald Article : The Seven Value Stream Mapping Tools. Journal of Operations \& Production Management, Vol. 17 Iss: 1 pp. 46-64

Ningtyas, Agnes Novita; Choiri, Mochamad; \&Azlia, Wifqi, 2011. Perancangan Ulang Tata Letak Fasilitas Produksi Dengan Metode Grafik dan Craft bUntuk Meminimisasi Ongkos material Handling, Jurnal Rekayasa Dan Manajemen Sistem Industri Vol. 3 No. 3. Hal 495-504.

Prasetyo, Christoporus Bagas. 2019. Identifikasi Dan Reduksi Waste Pada Proses Produksi Perlengkapan Bayi Menggunakan Metode Valsat Dengan 5W + 1 H Studi Kasus Pada Monica Collection. Skripsi. Fakultas Ekonomi dan Bisnis. Unika Soegijapranata. Semarang.

Pujawan, I. N., \& Er, M. (2017). Supply Chain Management. (Maya, Ed.) (Edisi 3). Surabaya: ANDI Yogyakarta.

Rivaldo, Jeffry Perangin-angin. 2019. Rancangan Pengendalian Kualitas Dengan Menggunakan Metode Six Sigma Pada Perusahaan Monica Collection Semarang. Sjripsi. Fakultas Ekonomi dan Bisnis. Unika Soegijapranata. Semarang. 
JEMAP: Jurnal Ekonomi, Manajemen, Akuntansi, dan Perpajakan

Safrial, \& Muhajir. 2016. Kualitas Dengan Metode Six Sigma. Jurnal Manajemen dan Keuangan, Vol 5(2), hal 1-12.

Tomadia, Widya, 2013. Evaluasi Penerapan Sistem Pengendalian Intern Untuk Persediaan Barang Dagangan Pada PT. Laris manis Utama Cabang Manado. Jurnal EMBA Vol.1 No. 3 Juni 2013, Hal. 20-29.

Widyarto, A, 2012. Peran Supply Chain Management Dalam Sistem Produksi Dan Operasi Perusahaan. BENEFIT. Jurnal Manajemen Dan Bisnis, Volume 16 No.2, Hal 91-98. 